\title{
PROSTORNA PERCEPCIJA U INŽENJERSKOM OBRAZOVANJU
}

\section{SPATIAL PERCEPTION IN ENGINEERING EDUCATION}

\author{
Lidija Pletenac*, Maura Jurić ${ }^{* *}$
}

\begin{abstract}
Sažetak
Sposobnost prostorne percepcije, neophodnu u STEM ${ }^{1}$ području, pratimo kod naših studenata $i$ prilagođavamo oblike rada potrebama studenta. Digitalizirali smo testove MRT i MCT te uveli multimedijalne nastavne materijale u e-kolegije. Slaba prostorna percepcija glavni je uzrok poteškoća pri rješavanju zadataka u prostoru na svim tehničkim kolegijima, posebno na geometrijskim. Prostorna percepcija razvija se vježbom. Rad analizira ovaj problem, daje prikaz rezultata ispitivanja (MRT i MCT) i primjene digitalnih nastavnih materijala. Analiza rezultata pokazuje poboljšanje kroz semestar.
\end{abstract}

Ključne riječi: prostorna predodžba, Mental Rotation Test, Mental Cutting Test

\begin{abstract}
Spatial perception abilities are necessary in STEM field, so we have been monitoring them and adapting our teaching methods to student needs. We digitized MRT and MCT tests and created new multimedia teaching materials for e-courses. Low spatial perception is the biggest problem in solving geometric tasks in space. This affects all technical courses, especially geometric ones. Spatial abilities develop with exercise. This paper analyzes this problem, gives an overview of MRT and MCT test results and describes the use of digital teaching materials.
\end{abstract}

Key words: spatial ability, Mental Rotation Test, Mental Cutting Test

\footnotetext{
* Sveučilište u Rijeci, Građevinski fakultet, Radmile Matejčić 3, 51000 Rijeka E-mail: lidija.pletenac@uniri.hr

** PRO-GRA-M d.o.o ,Antuna Barca 8, 51000 Rijeka

E-mail: dunatomaura@gmail.com

1 Science, Technology, Engineering and Mathematics
} 


\section{Uvod}

Za pretpostaviti je da student koji upisuje Građevinski fakultet ima afinitet prema prirodnim i tehničkim znanostima te da ima urođenu sposobnost prostorne predodžbe, barem u manjoj mjeri. Međutim, tijekom dugogodišnjeg rada sa studentima i praćenjem rezultata uspjeha u raznim oblicima kao što su samostalne ili grupne vježbe, seminari, individualni radovi - programi, pokazalo se da ta urođena sposobnost kod studenta nije dovoljna i nije garancija da će zadatak biti uspješno obavljen. Slaba predodžba otežava postizanje ishoda učenja [1].

Nažalost, sve je veći broj studenata koji imaju slabo razvijenu prostornu percepciju te ne mogu zamisliti objekt u prostoru: Iz dvodimenzionalnog prikaza objekta, tlocrta, nacrta i bokocrta ne mogu raspoznati o kakvom se objektu radi, koji dio je ispod, koji je iznad, što je vidljivo, a što skriveno od pogleda. Na mnogim se fakultetima stoga susreću s poteškoćama pri rješavanju zadataka u svim tehničkim kolegijima koji zahtijevaju razmišljanje u prostoru [2].

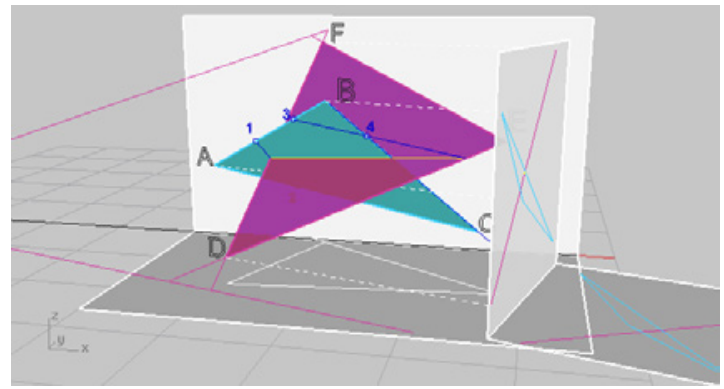

Slika 1. Presječnica dvaju likova, 3D model

Kako bi se olakšalo učenje i razvoj prostorne percepcije studenata, geometrijsko obrazovanje na našem fakultetu je digitalizirano (e-učenje, multimedijalni i interaktivni nastavni materijali, modeliranje u CAD ${ }^{2}$ itd.). CAD tehnologija koristi se od 1989. godine kroz razne softvere, a Rhinoceros od 2012. godine. Na vježbama su zastupljeni razni oblici rada, crta se na papiru, nakon čega se zadatak modelira u CAD-u. Primjer zadatka je na Slici 1.

Izradili smo [3], [4] digitalnu verziju testa mentalne rotacije (MRT) i testa mentalnog presjeka (MCT) kako bismo provjerili prostorne sposobnosti studenata te pokazali da ove sposobnosti rastu prema kraju kolegija. 


\section{Sposobnost prostorne percepcije}

\subsection{Područja prostorne percepcije}

Prostorna percepcija ili predodžba je prirodna sposobnost koja je u većoj ili manjoj mjeri urođena svakoj osobi. Naglo se razvija u adolescenciji, kasnije nešto sporije, a doseže maksimum do 30-tih godina. Dijelom je prirođena, a dijelom stečena vježbom tj. može se naučiti. Inženjerske sposobnosti percepcije razvijaju se kroz više godina.

Prostorna percepcija predstavlja dio ljudske inteligencije, dosta je istražena [5], [6], a obuhvaća više područja. Razni su autori ([2], [3], [7]) dali različite klasifikacije tih područja. Po jednoj klasifikaciji [3] to su: prostorna orijentacija, prikaz 3D objekta na $2 \mathrm{D}$ mediju, rješavanje $\mathrm{u}$ prostoru kroz crtež, brzo prostorno percipiranje i djelovanje. Uglavnom, prostorne sposobnosti obuhvaćaju mentalnu rotaciju, prostorne relacije i orijentaciju te prostornu vizualizaciju.

Dokazano je [6] da bavljenje deskriptivnom geometrijom i srodnim disciplinama razvija sva područja prostorne predodžbe. Konstruktivna geometrija, Geometrijska grafika i Inženjerska geometrija su kolegiji na kojima student razvija svoje urođene sposobnosti, a kako bi pomoću crteža rješavao i prikazivao prostorne tvorevine različitih geometrijskih oblika.

\subsection{Instrumenti provjere}

Kako bismo procijenili napredak studenata, potrebno je dobiti uvid u njihove ulazne kompetencije i usporediti ih s izlaznim kompetencijama. To se može provoditi na studiju pri upisu i na pojedinom kolegiju. Kako nemamo nikakve provjere pri upisu, provjere radimo na kolegiju: provjerava se prostorna predodžba, stil učenja te osnovno znanje iz pojedinog poglavlja (anonimni kviz). Ove provjere nisu obveza studenta, a neke od njih nose samo bonus bodove.

Kontrola kvalitete studija trebala bi sadržavati provjere ishoda učenja, dakle, temeljnih kompetencija, koje student građevine treba steći kroz akademsku godinu. To može biti jedan online kviz (poput ankete) koji je isti na svim građevinskim fakultetima u državi. Naime, ishodi učenja su važan instrument za $\mathrm{EQF}^{3}$ [1] i za $\mathrm{NQF}^{4}$.

\subsubsection{Mentalna rotacija i mentalni presjek (MRT i MCT)}

Kao instrumenti provjere prostorne percepcije razvijeni su razni testovi koji pokrivaju pojedina područja prostorne percepcije. Među njima su najpoznatiji MRT i MCT (napravljeni u SAD-u), a koji se primjenjuju širom

\footnotetext{
Europski kvalifikacijski okvir

4 Nacionalni kvalifikacijski okvir
} 
svijeta. Izvorna verzija bila je testiranje na papiru. Digitalnu verziju za MRT izradili smo 2016. a za MCT 2017. godine u obliku Moodle kvizova, koji se ocjenjuju automatski. Dobili su naziv D-MRT i D-MCT.

\subsubsection{Stilovi učenja}

Individualne razlike u sklonostima i sposobnostima studenata rezultiraju različitim pristupima učenju. U literaturi su razrađeni brojni modeli o stilovima učenja pojedinca [1]. Našim studentima u e-kolegiju nudimo Felder-Silvermanov model kroz online upitnik "Index of Learning Styles". Nakon toga slijedi skup savjeta o učenju u skladu s vlastitim stilovima učenja. Kad studenti upišu svoje rezultate u zaseban upitnik e-kolegija, mi dobivamo podatke o studentskim stilovima učenja, potrebne za oblikovanje nastavnih aktivnosti i izbor materijala.

\section{Digitalizirana konstruktivna geometrija}

Već desetljećima inženjeri rade u digitalnom okruženju, a računalna grafika i CAD modeliranje unaprijedili su crtanje te su sastavni dio brojnih programskih paketa za proračun konstrukcija i temelj za BIM ${ }^{5}$. Desetljećima se geometrijski kolegiji našeg fakulteta digitaliziraju i stalno mijenjaju. Studenti uče rješavati 3D probleme i uz pomoć CAD-a, no, prije svega, ideja mora biti jasna u mislima. Primjeri zadataka prikazani su na Slici 2.
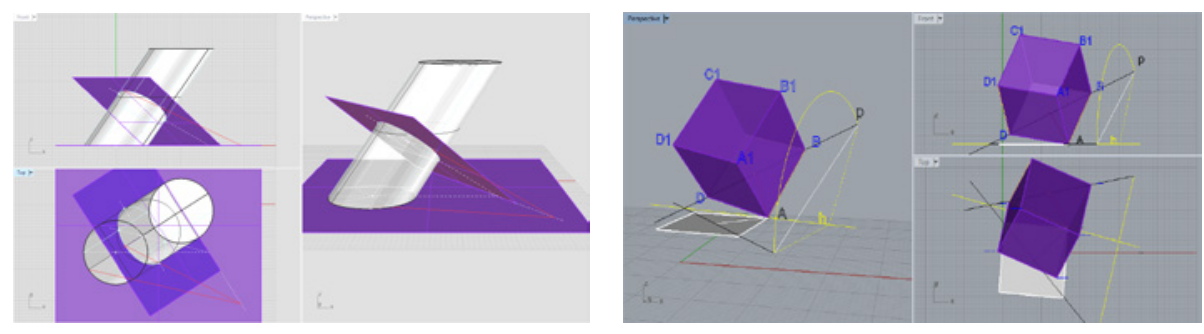

Slika 2. Vježbe: Presjek valjka (stupa) i kocka u prostoru

E-učenje se u geometrijskim kolegijima na našem, Građevinskom fakultetu u Rijeci koristi od 2007. godine. Doseglo je 3. razinu razvijenosti, prema [1], u obliku hibridne nastave: svaki e-kolegij sadrži materijale prema nastavnim cjelinama, oblikovane prema metodičkim principima i dopunjene video tutorialima. Obuhvaća bodovanje studentskih online i offline aktivnosti, predaju i ocjenjivanje radova. Tu su vježbe s predlošcima

5 Building Information Modeling 
u 3D i 2D, prezentacije s predavanja, domaće zadaće, 3D modeli, upitnici o razumijevanju pojedine teme, kvizovi, forumi, fotografije objekata, itd.

E-kolegij sadrži e-knjigu koja se sastoji od teorijske podloge i praktičnih vježbi, primjera primjene geometrije u građevinarstvu, arhitekturi, niskogradnji, itd. Svi nacrti su izrađeni u CAD-u s poveznicama na odgovarajuće 3D modele i video tutoriale, koje studenti mogu koristiti od kuće, s web-a. U e-knjizi obrađene su sve teme kolegija: opisno, grafički i fotografijama koje prikazuju primjenu određene teme u struci. Na Slici 3 i 4 prikazani su neki od zadataka, riješenih modeliranjem u CAD-u.

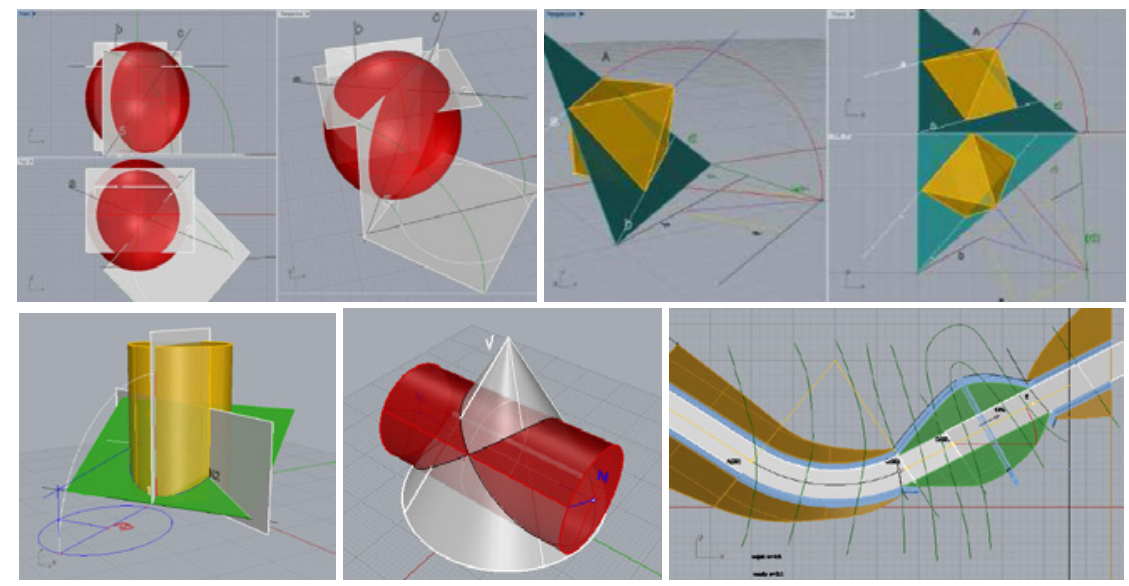

Slika 3. Zadaci riješeni u CAD-u (3D modeliranje)

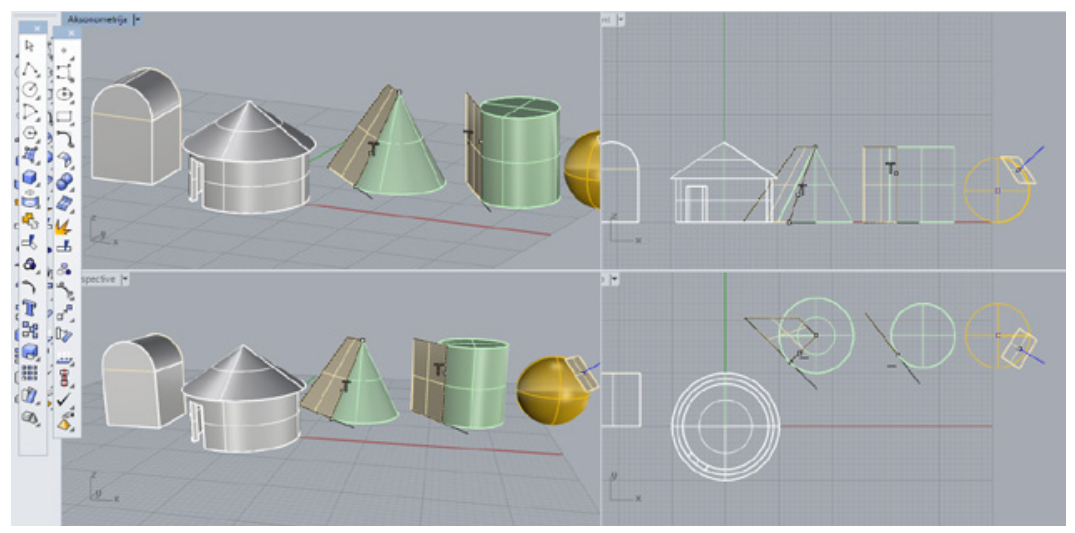

Slika 4. Primjena aksonometrije i perspektive u CAD-u

Kako bi student mogao (korak po korak) vježbati rad s CAD-om u 3D prostoru, ponuđeni su video tutoriali za gotovo svaki zadatak koji se tijekom nastave rješava (na papiru i u CAD-u). 


\section{Rezultati primjene D-MRT i D-MCT}

Na sveučilišnom i stručnom studiju od 2016. g. digitaliziranim online testovima D-MRT i D-MCT testiraju se dvije komponente prostorne percepcije: mentalna rotacija i mentalni presjeci.

Pri izradi D-MRT napravljen je prikaz svih objekata u perspektivi (Rhinoceros). Svaki zadatak ima na lijevoj strani zadani objekt, a desno rotirane objekte, od kojih su dva jednaka zadanom, a student ih treba naći. Na Slici 5 točno rješenje su prvi i četvrti objekt.

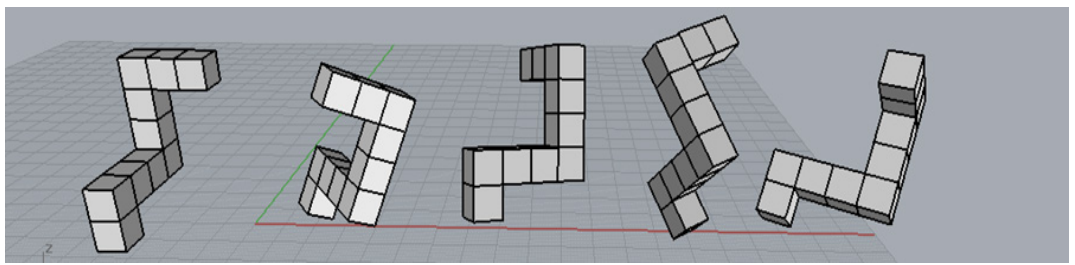

Slika 5. Jedan zadatak digitaliziranog MRT

\subsection{Mental Rotation Test na Konstruktivnoj geometriji 2017/18.}

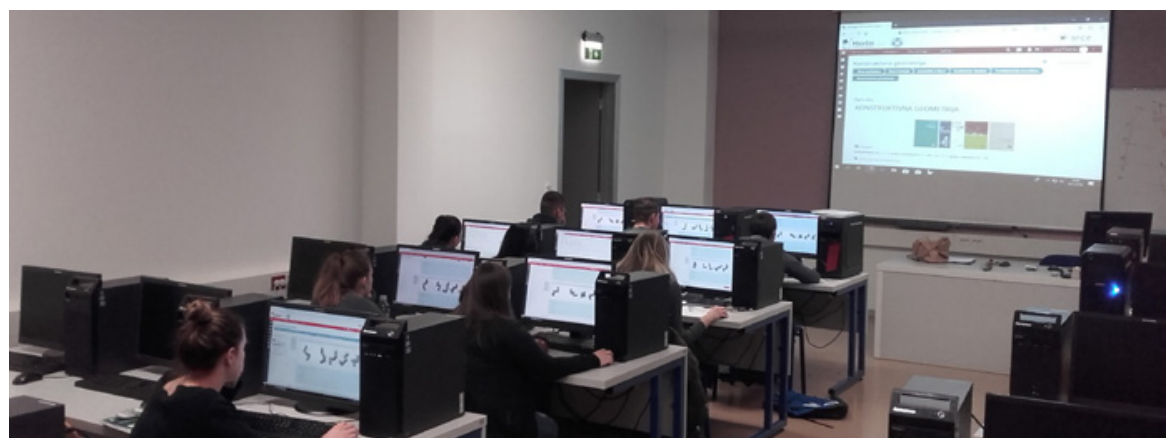

Slika 6. Testiranje D-MRT u trajanju od 3 minute

U prošloj ak. god. 2017./18. studenti su pisali digitalizirane testove prostornog zora (Slika 6). U prvom semestru pokazali su slabije rezultate na D-MRT1 u listopadu i nešto bolje rezultate na D-MRT2 u siječnju (Slika 7).
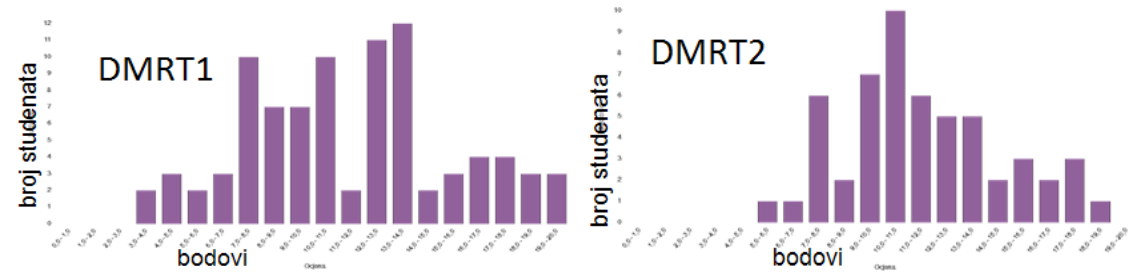

Slika 7. Bodovi D-MRT1 i D-MRT2 u 1. sem 2017/18. 
U drugom semestru 2017./18., u okviru izbornog kolegija Inženjerska geometrija studenti su pisali digitalizirane D-MRT1 i D-MRT2 i postigli vidno bolje rezultate nego u prvom semestru (Slika 8). Dva semestra bavljenja geometrijom poboljšala su sposobnosti studenata koji su upisali ovaj izborni kolegij na početku studija i nisu mogli promijeniti svoj izbor. Ti studenti nisu na Konstruktivnoj geometriji bili najbolji.

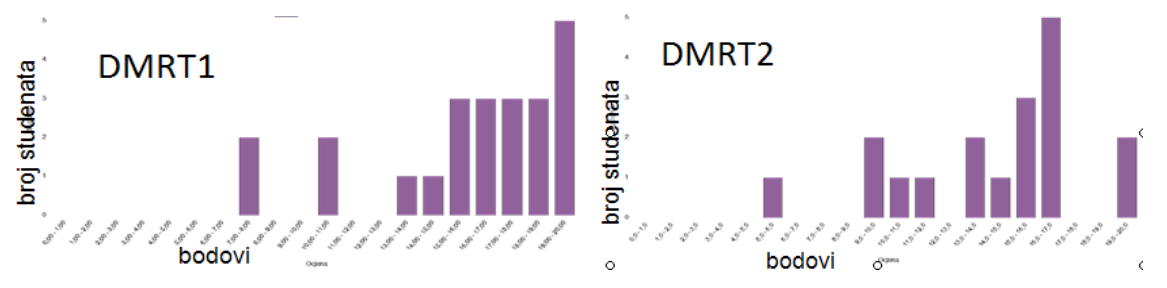

Slika 8. Bodovi D-MRT1 i D-MRT2 u drugom semestru

\subsection{Mental Cutting Test}

Sposobnost zamišljanja presjeka objekta, potrebna u poglavlju "Presjeci", testira se kroz D-MCT. Svaki zadatak ima na lijevoj strani objekt i ravninu koja ga siječe (Slika 9), prikazanu pravokutnikom, a na desnoj strani samo jedan od ponuđenih likova ima točan oblik presjeka tog objekta ravninom. Student ga treba naći. U zadatku na Slici 9 to je četvrti lik.

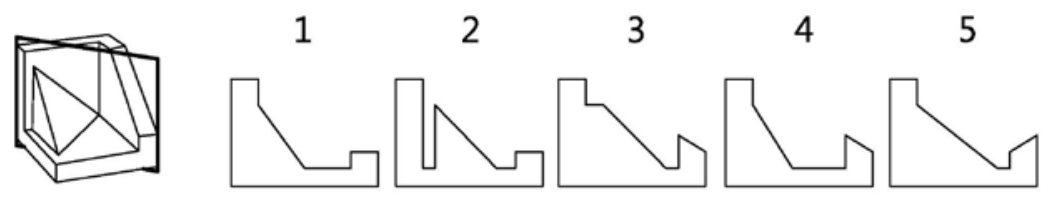

Slika 9. Primjer zadatka iz D-MCT

Na Konstruktivnoj geometriji u prvom semestru studenti su rješavali D-MCT i pokazali slabiji uspjeh (Slika 10 lijevo). U drugom semestru, baveći se Inženjerskom geometrijom, studenti su postigli znatno bolji rezultat (Slika 10 desno).
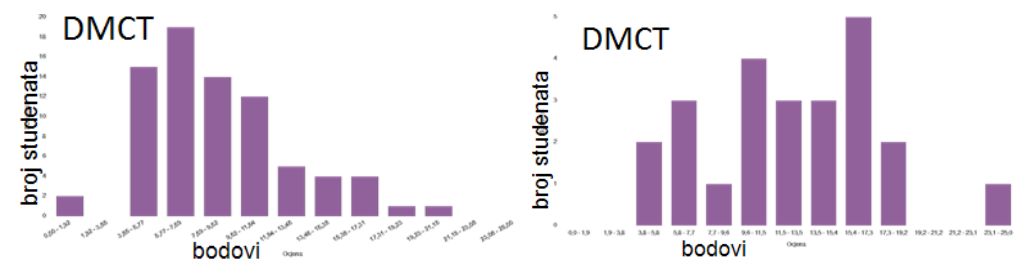

Slika 10. Uspjeh na D-MCT и 1. i u 2. semestru 
Rješavajući geometrijske zadatke u prostoru, studenti su 2017./18. poboljšali svoju prostornu percepciju. Prolaznost na ispitu bila je $100 \%$. Nažalost, u akademskoj godini 2018./19. Inženjerska geometrija se nije predavala jer je dozvoljena promjena izbornog kolegija pa su se neki studenti prebacili na „lakši“ kolegij, a na ovom kolegiju ostalo je manje od 10 studenata. Nastava je održana konzultativno i online.

\section{Inovacije nakon D-MRT i D-MRT}

Nakon provjere prostorne percepcije, u akademskoj godini 2016./17. uvedene su novosti: Izrađen je model proširene stvarnosti Augmented Reality Sandbox [8] za učionicu, (drugi u Hrvatskoj), koji koristi softver razvijen na UC Davis. Služi za predavanje, vježbu i modeliranje programa. Student može sam modelirati svoj individualni zadatak (Slika 11).

Osim novih CAD modela objekata te više riješenih zadataka, uvedene su i igre kao dio vježbe ("gaming"). Jedna od njih je "Nacrtaj skriveni objekt", koji se dobije u vrećici, a dohvaća se rukom, bez gledanja. Druga je „Pentomino puzzle“. Zastupljen je timski rad, transformacije se uvježbavaju kao igre. Semestar počinje skiciranjem hrpe kocki, složenih na stolu, u neki novi oblik. D-MCT i D-MRT dostupne su izvan nastave, kao igre za vježbu prostorne predodžbe.

Već punih 40 godina uvode se inovacije u nastavu geometrijskih kolegija, kao prilagodbe potrebama studenata (bila je tu i igra "Milijunaš"). Te potrebe su sve veće, a sve je manje sati nastave i angažmana studenata.
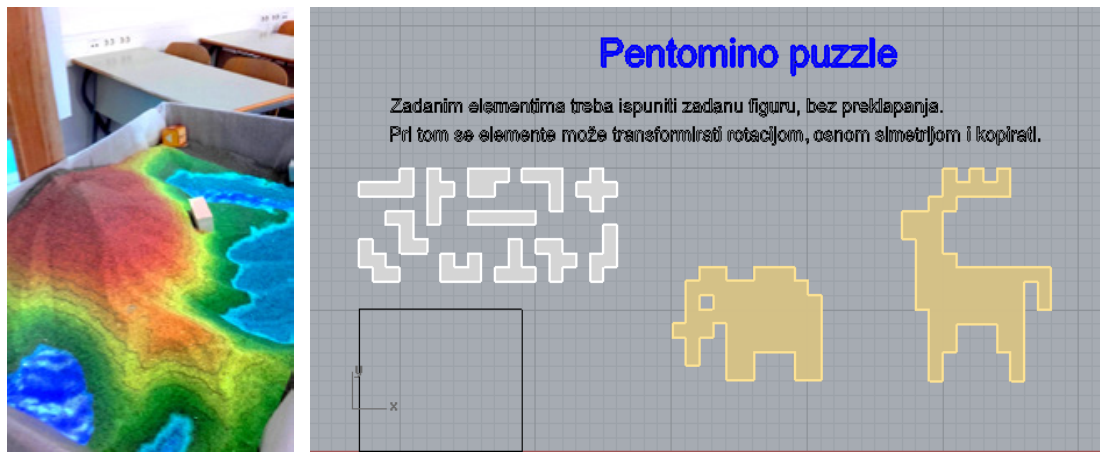

Slika 11. AR Sandbox i vježba rotacije likova

\section{Analiza rezultata testova 2018./19.}

\subsection{Mental Rotation Test}

Na Konstruktivnoj geometriji 2018./19. u prvom pokušaju rješavanja D-MRT1 (listopad) studenti su točno riješili u prosjeku 47,1\% zadataka. Histogram bodova koje su studenti postigli prikazan je na Slici 12. 

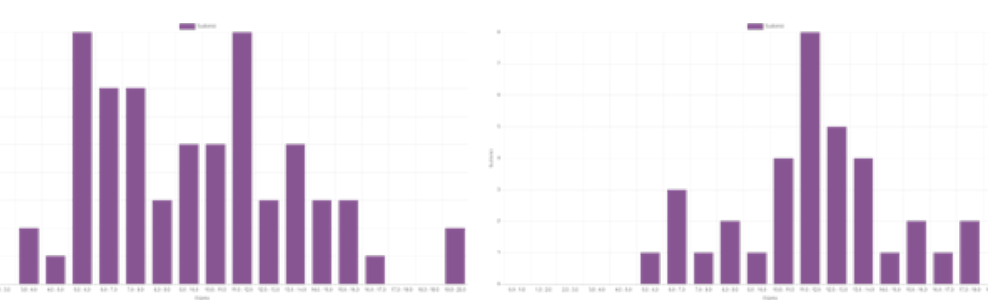

Slika 12. Bodovi u 1. pokušaju D-MRT1 i D-MRT2

Razdioba rezultata D-MRT1 (Slika 12) nije Gaussova, već pomaknuta ka slabijim rezultatima. Ukupan rezultat je slabiji nego lani. Ovaj test ukazuje kako se većina novoupisanih studenata teško snalazi s 3D objektom, premda ga vidi u perspektivi. Za buduće inženjere ovo je veliki problem. Trend opadanja prostornog zora prisutan je godinama i u drugim zemljama [2], [4]. Zato je D-MRT1 ponuđen studentima za vježbanje izvan nastave. Na drugom dijelu testa, na D-MRT2, na sličnim zadacima pokazali su se nešto bolji rezultati (Slika 12), no ipak slabiji nego lani.

Neki studenti nisu ponovno rješavali test, neki su pogledali i predali nedovršeno, neki su odustali. Pri kraju semestra, najviša ocjena postignuta na testu D-MRT1 prikazana je na Slici 13. Testu su pristupila 64 studenta. Prosjek je 50,8\% točno riješenih (10,2 boda).

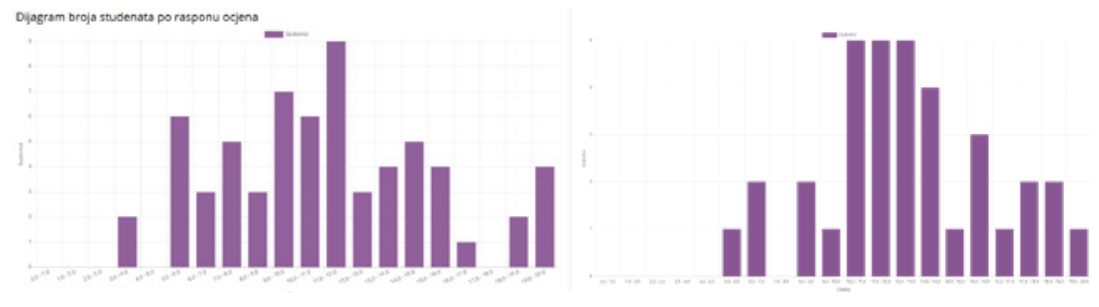

Slika 13. Bodovi D-MRT1 i D-MRT2 zadnji pokušaj

Na Slici 13 vidljiv je pomak rezultata D-MRT1 i D-MRT2 prema boljima u odnosu na početak semestra.

\subsection{Mental Cutting Test}

Ista generacija studenata rješavala je D-MCT. Zadatak br. 25 pokazao se studentima najtežim (Slika 14). Stoga je izrađen CAD model na kome je zadatak prikazan u fazama rješavanja. 

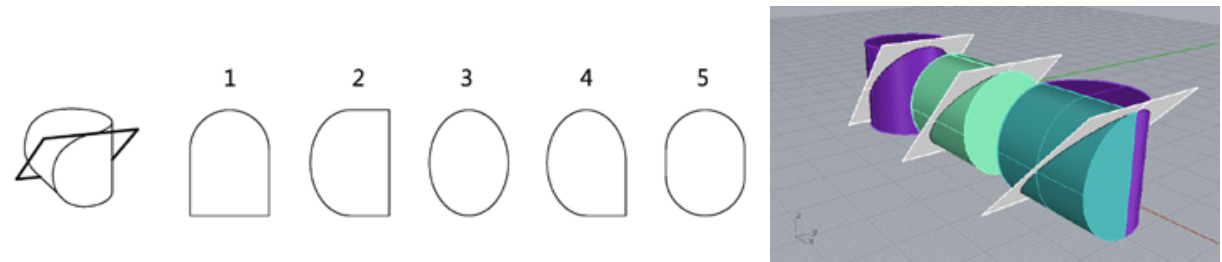

Slika 14. Najslabije riješen zadatak (br. 25) u D-MCT

Prvi pokušaj rješavanja D-MCT na Konstruktivnoj geometriji 2018./19. rezultirao je prosjekom od 40,8\% točno riješenih zadataka $(10,2$ boda od 25). Test su rješavala 42 studenta. (kroz listopad, studeni, ...)
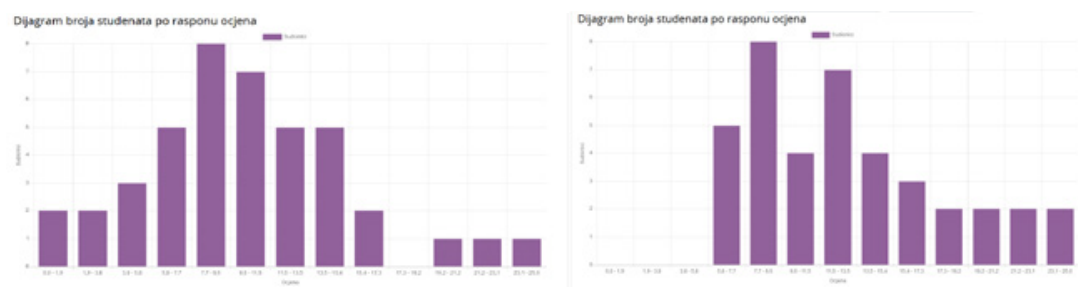

Slika 15. Bodovi D-MCT za prvi pokušaj i najbolji postignuti rezultat

Najbolji rezultat postignut kroz semestar, bez obzira je li netko rješavao samo prvi put, prikazan je na Slici 15 desno. Prosjek je 52,4\% točno riješenih zadataka (13,1 bod), postignut do kraja semestra.

\subsection{Korelacije D-MTR i D-MCT na Konstruktivnoj geometriji}

Za studente koji su pisali sve testove, D-MRT1, D-MRT2 i D-MCT, zanima nas postoji li korelacija između uspjeha u testiranim dvjema komponentama prostorne percepcije: misaonoj rotaciji i sječenju. Kod oba testa postoji vjerojatnost slučajnog pogađanja rješenja. D-MRT 1 i 2 nose po 20 bodova, a MCT 25 bodova. To se preračuna u bonus-bodove.

Pokazalo se da u generaciji 2018./19. korelacija između studentskih rezultata D-MRT i D-MCT postoji (Slika 16). Razne aproksimacijske krivulje, polinom i logaritamska krivulja (trend lines) se gotovo poklapaju s linearnom regresijom (Slika 16). Kod najboljih i najslabijih studenata zapaža se sljedeće: oni koji su bolji u jednom testu, uglavnom su bolji i u drugom, premda testiramo različite komponente prostorne predodžbe. Kod srednje uspješnih iz promatrane skupine, podaci su raspršeni, kao što je vidljivo na Slici 16, pa je kod njih ta korelacija zanemariva. 
Linearna regresija MRT - MCT

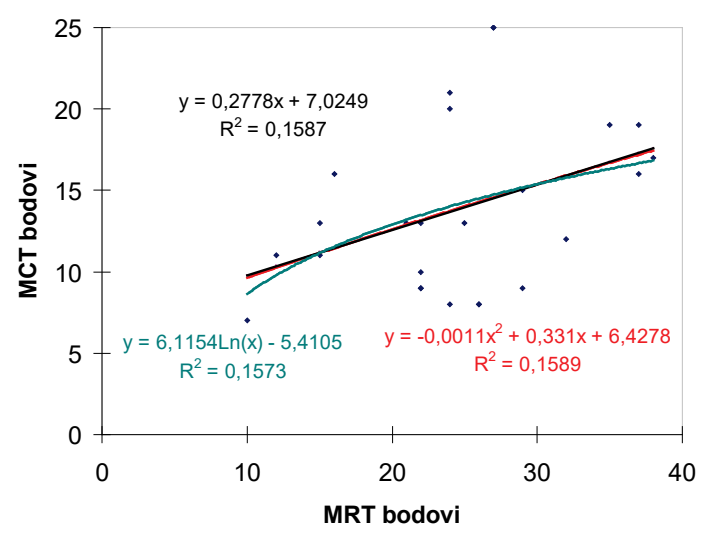

Slika 16. Linearna regresija za D-MRT i D-MCT

\subsection{Korelacije s pojedinim aktivnostima}

\subsubsection{Korelacija prostorne percepcije i programa}

Programi u Konstruktivnoj geometriji nose do 50 bodova pa se studenti trude prijeći bodovni prag u ovoj aktivnosti. Grafički prikaz korelacije prostorne percepcije i postignutih bodova programa prikazan je na Slici 17.

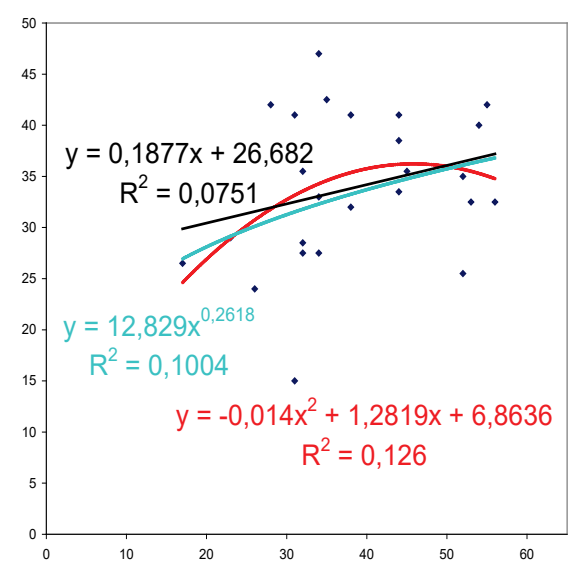

Slika 17. Veza prostorne percepcije i programa

Linearna regresija ukazuje na postojanje korelacije. Ako se podaci aproksimiraju raznim krivuljama, sve one pokazuju jaču korelaciju kod studenata sa slabijom prostornom percepcijom. Kod najboljih studenata podaci su raspršeni i korelacija se ne vidi, a polinom 2. stupnja čak simulira 
kako je nema. Raspolažemo s vrlo malo podataka $(\mathrm{N}=25)$, ali tu su svi studenti koji su pristali pisati sva tri testa percepcije za bonus bodove.

\subsubsection{Korelacija s provjerom vježbi i zadaća}

Situacija je obrnuta kod aktivnosti za koje se studenti ne pripremaju (Slika 18): Vježbe se provjeravaju kroz kviz o riješenoj vježbi, provjeru zadaće i aktivnost na satu, a nose 20 bodova.

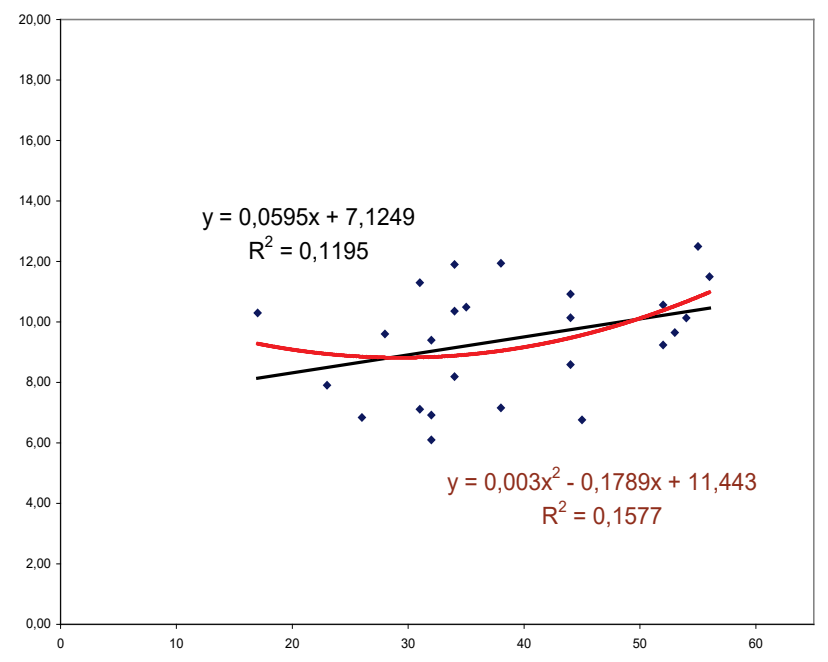

Slika 18. Veza s provjerom vježbi

Studenti rade kampanjski pa na ovim provjerama većinom pokazuju nepripremljenost i neriješene zadaće. Ovdje su također izostavljeni studenti koji nisu pisali sva tri testa prostorne percepcije.

Krivulje (trend line) koje mogu aproksimirati ove podatke gotovo se poklapaju s pravcem (veza je skoro linearna). Polinom simulira obrnutu situaciju od one kod programa: korelacija je izražena kod studenata $s$ najboljom prostornom percepcijom, koju su vjerojatno razvili jer redovito uče (Slika 18). Kod ostalih je ta korelacija slaba.

\subsubsection{Korelacija prostorne percepcije s uspjehom na ispitu}

Rezultat testa prostorne predodžbe, dostignute kroz semestar, uspoređen je s bodovima postignutim isključivo na ispitu, bez obzira jesu li ga studenti položili. Ova korelacije za Konstruktivnu geometriju 2018./19. grafički je prikazana na Slici 19: linearna regresija ukazuje da postoji korelacija. Aproksimacijske krivulje, polinom i logaritamska krivulja pokazuju istu tendenciju kao u slučaju programa: značajniju korelaciju kod slabijih i srednje uspješnih studenata. 


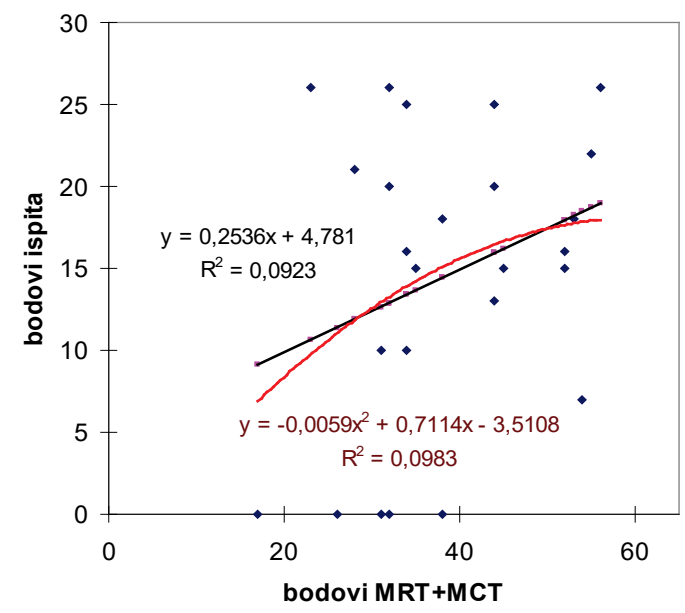

Slika 19. Veze prostorne percepcije s ispitom

Podaci jako variraju, studenti slabije nadarenosti uspijevaju položiti, ali i nadareni uspijevaju pasti na ispitu. Nadarenost ne garantira uspjeh, ali rad ga garantira, čak i uz slabiju nadarenost.

\subsubsection{Usporedba svih triju aktivnosti}

Na Slici 20 vidi se usporedba vježbi, programa i ispita u funkciji pokazanih sposobnosti prostornog zora. Ovdje su kao regresijske krivulje promatrani pravac i polinom 3. stupnja, koji je fleksibilniji od pravca i krivulje 2. stupnja. Programi su uvjet za pristupanje ispitu, lagani su i rade se uz podršku nastavnika. Stoga ova aktivnost pokazuje relativno najbolji uspjeh, rezultat rada, kojem malo pridonose sposobnosti. Kako na vježbe studenti većinom dolaze nespremni, bez učenja, prostorni zor im gotovo ne pomaže. 


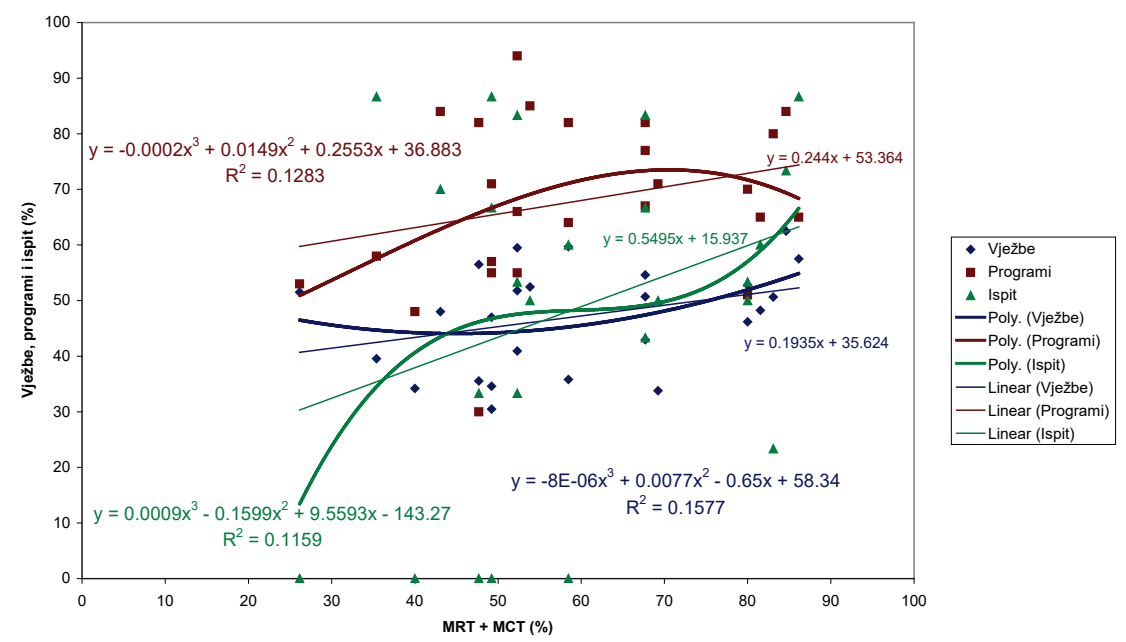

Slika 20. Usporedba korelacije sposobnosti i uspjeha po aktivnostima

Neki studenti nisu još položili ispit u vrijeme obrade ovih podataka pa se to vidi na grafu. Bodovi su preuzeti iz e-kolegija. Ako korelacije prikažemo pravcima, iz koeficijenta smjera regresijskog pravca vidi se da prostorna percepcija ima najveći utjecaj na ispit $(\mathrm{k}=0.55)$, a najmanji na vježbe $(\mathrm{k}=0.19)$. Studenti boljih sposobnosti razumiju gradivo, lakše uče i na kraju semestra bolje rješavaju ispit. Vidi se i to da studenti, koji uče više, postižu bolju sposobnost prostorne percepcije. Ima i onih koji su pokazali dobru percepciju, ali ne i znanje, jer ne uče. Podaci su jako raspršeni kod srednje uspješnih.

\section{Zaključak}

Pri rješavanju zadataka programa i ispita prostorna predodžba korelirana je s uspjehom. Kao i mnogo puta do sada, pokazalo se da je prostorna predodžba preduvjet za uspješno rješavanje zadataka u svim tehničkim kolegijima u kojima student rješava zadatke u prostoru.

Iz rezultata se može iščitati kako urođena prostorna predodžba kod studenata nije dovoljna za uspjeh te da se ona razvija vježbom.

Analiza rezultata D-MRT i D-MCT dobivenih na početku semestra u usporedbi s onima na kraju semestra pokazuju kako redovito učenje tijekom semestra, intenzivan rad na individualnim ili grupnim vježbama i rad na računalu gdje student uči rješavati probleme u 3D (imajući pri tome jasnu viziju ideje u mislima) svakako pridonose razvoju prostorne predodžbe. Stoga ćemo vježbe početi nagrađivati s više bodova nego programe. Nakon drugog semestra rezultati su znatno bolji. Studentu trebaju dva semestra bavljenja geometrijom u 3D prostoru. 
Nažalost, analiza rezultata pokazuje i jednu negativnost. Naime, rezultati testova i ispita u akademskoj godini 2018./19. pokazuju trend pada uspješnosti na geometrijskim kolegijima (nakon smanjenja broja sati predavanja) i mali broj studenata koji su redovitim učenjem uspjeli razviti prostornu percepciju. U trendu je kampanjsko učenje, pred provjeru.

Crtanje u 3D pomoću video tutoriala, izrada papirnatih modela geometrijskih tijela, razne igre s modelima, mogućnost individualnog modeliranja terena kod poglavlja "Kotirana projekcija” pomoću Augmented Reality Sandbox-a, sve su to aktivnosti koje razvijaju prostornu predodžbu kod studenta, naravno uz pretpostavku da student redovito savladava sve teme kolegija, od najlakših do najzahtjevnijih.

\section{Literatura}

[1] Divjak, B. (2008.) Ishodi učenja u visokom školstvu. Fakultet organizacije i informatike, Varaždin

[2] Gorska, R. (2005.) Modern Research on Spatial Abilities - an Overview and New Results. 11th Scientific and professional Colloquium of CSCGCG: Summary of Abstracts. Croatian society for geometry and graphics, Zagreb

[3] Kušar, D., Pletenac, L., Volgemut, M. (2017.) Digitalisation of Mental Rotation Test. Abstracts, 20th Scientific-Professional Colloquium on Geometry and Graphics. CSGG, Zagreb

[4] Kušar, D., Volgemut, M., Pletenac, L. (2018.) Digitalization of Spatial Abilities Tests. Proceedings of 18th ICGG. ISGG, Milan, Italy

[5] Linn, M. C., Petersen, A. C. (1986): A Meta-Analysis of Gender Differences in Spatial Ability: Implications for Mathematics and Science Achievement. J. S. Hyde \& M. C. Linn (eds.), The psychology of gender: Advances through metaanalysis. Baltimore, Johns Hopkins Uni-versity Press.

[6] Suzuki, K. .(2014)Traditional Descriptive Geometry Education in the 3D-CAD/CG Era. Journal for Geometry and Graphics, Vol 18. Heldermann Verlag, 2014.

[7] Yilmaz, B. (2009): On the Development and Measurement of Spatial Ability. International Electronic Journal of Elementary Education. 1(2).

[8] https://arsandbox.ucdavis.edu/ (06.07.2019.) 
